\title{
Neurofibroma Telinga Tengah dengan Otitis Media Supuratif Kronis
}

\author{
Arsia Dilla Pramita, Jacky Munilson, Yan Edward
}

\begin{abstract}
Abstrak
Pendahuluan: Neurofibroma adalah tumor saraf yang cukup sering dijumpai, tetapi hanya beberapa kasus yang melibatkan telinga tengah yang pernah dilaporkan. Kasus: Dilaporkan seorang perempuan berusia 51 tahun dengan keluhan telinga kiri berair, hilang timbul sejak 30 tahun yang lalu. Pasien dilakukan tindakan timpanomastoidektomi dinding utuh telinga kiri, intraoperatif ditemukan jaringan granulasi beserta jaringan berpapilpapil di liang telinga. Hasil patologi anatomi adalah neurofibroma dengan kalsifikasi. Kesimpulan: Neurofibroma merupakan suatu tumor yang dapat muncul dimana saja di tubuh. Adanya neurofibroma bersamaan dengan OMSK diduga akibat peranan inflamasi yang mencetuskan timbulnya tumor. Tatalaksana dan follow up yang baik dapat memberikan hasil yang memuaskan.
\end{abstract}

Kata kunci: Neurofibroma, Telinga Tengah, OMSK tipe aman fase tenang

\begin{abstract}
Introduction: Neurofibroma are nerve tumors that relatively common, but only a few cases involving the middle ear have been reported. Case Report: Reported a 51 -year -old woman, with chief complain discharge coming out from her left ear since 30 years ago intermittently. We performend tympanomastoidectomy canal wall up to her, intraoperatif we found that granulation tissue with some papilomatous tissue. The results of anatomic pathology was neurofibroma with calcification. Conclusion: Neurofibroma is a tumor that can arise anywhere. We suggest there was a role of inflammation that casuse this neurofibroma accompanied with chronic suppurative otitis media $A$ good treatment can bring a satisfactory result to this case.
\end{abstract}

Keywords: Neurofibroma, Middle ear, Chronic suppurative otitis media

Affiliasi penulis Bagian Telinga Hidung Tenggorok Bedah Kepala Leher FK Unand/ RSUP DR. M. Djamil Padang

Korespondensi :Arsia Dilla Pramita (arsiadilla@gmail.com)

Telp: 081373807231

\section{PENDAHULUAN}

Neurofibroma merupakan tumor jinak yang cukup sering dijumpai, namun hanya beberapa kasus yang melibatkan telinga tengah pernah yang dilaporkan. Neurofibroma dapat tumbuh dimana saja di tubuh yang terdapat sel saraf. ${ }^{1,2}$

Neurofibroma adalah tumor selubung saraf perifer yang muncul akibat hambatan inaktivasi gen biallelic pada neurofibromin. Tumor ini terdiri dari proliferasi dari ssemua elemen pada selubung saraf. Neurofibroma dapat berasal dari sistem saraf, termasuk sel schwann, neuron, fibroblast dan sel perineural. Neurofibroma bisasanya jinak. Transformasi menjadi keganasan telah dilaporkan muncul pada 2 sampai $16 \%$ kasus. Bahwa neurofibroma dapat berubah menjadi neurofibrosarkoma. 1,2,3

\footnotetext{
Jenis Neurofibroma

Terdapat dua subtype utama dari neurofibroma yang kelompokkan berdasarkan kedalaman dari keterlibatan tumor;
}

\section{Kutaneus neurofibroma}

Kutaneus neurofibroma juga dikenal dengan dermal neurofibroma. Tumor ini tumbuh dari saraf kecil di kulit atau tepat di bawah kulit dan muncul sebagai benjolan kecil yang khasnya muncul pada waktu pubertas. Tumor ini dapat muncul tunggal, atau multipel. Neurofibroma kutaneus jarang menimbulkan masalah medis yang serius, tetapi dapat menjadi gatal atau nyeri jika terbentur. Sangat penting untuk diperhatikan bahwa tumor ini tetap akan menjadi jinak sepanjang hidup dan tidak akan menjadi ganas. Tumor ini dapat menyebabkan masalah kosmetik yang signifikan dan seringkali memerlukan pengangkatan. Kutaneus neurofibroma adalah tumor yang dapat ditemui hampir ada semua pasien NF1 dewasa. ${ }^{2,3,4}$

2. Pleksiform neurofibroma

Pleksiform neurofibroma adalah tumor besar, yang lebih luas yang tumbuh dari saraf mana saja di tubuh. Tumor ini berbatas tegas namun tidak berkapsul. Pleksiform neurofibroma sering ditemukan pada anak kecil, kadang-kadang muncul saat lahir. Pleksiform neurofibroma dapat berlokasi di sekitar kantong mata, wajah, lengan, kaki, punggung, dada, atau abdomen. ${ }^{2,4}$

$10-15 \%^{2}$ dari tumor ini dapat bertransformasi menjadi ganas yang dikenal Malignant peripheral Nerve Sheath Tumor (MPNST). Tidak ada test yang 
dapat diandalkan untuk menskrining MPNST. Namun demikian, individu dengan pleksiform neurofibroma harus mencermati jika terdapat nyeri yang berkelanjutan pada tumornya, cepatnya pertumbuhan tumor, pengerasan dari tumor atau kelemahan atau kebas pada lengan atau kaki pada penderita pleksiform neurofibroma. Ini adalah tanda terjadi perubahan ke arah keganasan, dan oleh karena itu, morbiditas dari pleksiform neurofibroma lebih tinggi daripada dermal/kutaneus neurofibroma. $2,3,4$

\section{Tatalaksana Neurofibroma}

Manajemen pembedahan adalah satusatunya terapi jika neurofibroma telah menyebabkan disabilitas, nyeri atau perubahan bentuk. Reseksi komplit dari suatu neurofibroma sangat sulit karena sifatnya yang infiltrative, masalah dengan perdarahan dan situasi anatomi secara umum. Manajemen pembedahan dari neurofibroma secara umum memerlukan perhatian terhadap luasnya reseksi tambahan dengan perkiraan kemungkinan rekuren dan hilangnya fungsi dari organ tersebut. , $^{1,4,5}$

Neurofibroma berkembang sepanjang usia, dan dipegaruhi oleh kehamilan dan pubertas. Pada dewasa pengangkatan tumor secara subtotal menyebabkan rendahnya angka kekambuhan. Untuk meminimalisir angka kekambuhan post operatif, sangat penting untuk memotong tumor sampai batas bebas tumor minimal $1 \mathrm{~mm}$ karena sempitnya lokasi. tanpa menyebabkan kehilangan fungsi fisiologis. 1,4,5

\section{Otitis Media Supuratif Kronis}

Otitis Media Supuratif Kronis (OMSK) adalah radang kronis telinga tengah dengan perforasi membran timpani dan riwayat keluarnya sekret dari telinga (otore) tersebut lebih dari tiga bulan. OMSK dibagi menjadi dua tipe, tipe aman dan tipe bahaya. 6,7

Terjadinya otitis media disebabkan oleh banyak faktor antara lain infeksi virus atau bakteri, gangguan fungsi tuba, alergi, kekebalan tubuh, lingkungan dan sosial ekonomi. Kadang infeksi berasal dari telinga luar masuk ke telinga tengah melalui perforasi membran timpani. Maka terjadilah proses inflamasi. Kelainan ini akan mengakibatkan terperangkapnya bakteri dalam mukosa telinga tengah, kadang terbentuk jaringan granulasi pada daerah tersebut.6,7

Mukosa telinga tengah mempunya keampuan untuk kembali normal, namun bila terjadi perforasi membran timpani yang permanen, mukosa telinga tengah akan terpapar ke dunia luar sehingga memungkinkan terjadinya infeksi berulang setiap waktu. Bila tidak terjadi infeksi maka mukosa telinga tengah tampak tipis dan pucat, jika terdapat fokal infeksi terjadilah infeksi eksaserbasi akut yang ditandai dengan sekret yang mukoid atau mukopurulen, dan pulsasi di dekat tuba eustachius. ${ }^{6,7}$

Episode berulang dari otore dan perubahan mukosa menetap ditandai juga dengan osteogenesis, erosi tulang dan osteitis yang mengenai tulang mastoid dan osikel. Setiap pasien dengan otore kronis harus mendapat pemeriksaan otoskopi dengan teliti dan dibersihkan liang telinganya. Bila terdapat perforasi, ditegakkan dengan diagnosis OMSK. Kemudian ditentukan apakah ada tanda komplikasi yang memerlukan pengobatan segera, bila tidak ada komplikasi, ditentukan tipe OMSK, tipe benigna atau tipe bahaya. 6,7

Penatalaksanaan OMSK untuk kasus dimana penyakitnya secara medis tidak dapat sembuh akibat onsetnya dan tendensi progresifitas penyakitnya sebaiknya mendapat terapi operatif. OMSK yang disertai peradangan mukosa difus, karena diikuti dengan osteitis dan pembentukan jaringan granulasi di kavum timpani dan rongga mastoid umumnya sukar diatasi dengan medikamentosa saja. Tujuan jangka panjang adalah usaha menutup perforasi membran timpani dan memperbaiki pendengaran secara konservatif maupun operatif. ${ }^{6,7}$

\section{Inflamasi dan Tumor}

Peradangan dikatakan sebagai penyebab tumor yang ditemukan berdasarkan, epidemiologi dan gambaran klinis. Tumor umumnya ditimbulkan oleh agen infeksius yang menginduksi reaksi inflamasi pada organ spesifik tidak terkait satu sama lain. Namun demikian, secara umum terdapat patogenesis yang sama. $8,9,10$

Tumor pada dasarnya adalah suatu penyakit kronis yang diduga timbul akibat faktor usia, urbanisasi, dan gaya hidup yang tidak sehat. Adanya inflamasi kronis yang dikarakteristikkan adanya peningkatan level peradangan sistemik dari sitokin dan protein yang terkait dengan inflamasi (C- reaktif protein) adalah suatu mekanisme yang mendasarinya. ${ }^{8,9,10}$

Bertambahnya usia, faktor makanan, dan tidak aktif secara fisik, mutasi dan kesalahan pada replikasi, polusi lingkungan, radiasi dan sinar ultraviolet saat ini juga dikaitkan dengan tumorigenesis Namun demikian, inflamasi yang menetap dari suatu infeksi atau autoimun merupakan temuan yang sangat bermakna pada kejadian tumorigenesis. Peradangan memainkan peranan yang sangat penting pada tiap derajat perkembangan tumor, termasuk inisiasi, promosi, perubahan menadi keganasan, invasi dan metastasis. Infamasi juga mempengaruhi sistem imun dan respon terhadap terapi. ${ }^{8,9,10}$

Hubungan antara peradangan dan tumor pertama kali di cetuskan oleh Galenus sekiar 1800 tahun yang lalu. Dia menyimpulkan bahwa tumor yang muncul akibat inflamasi jaringan, dan kedua hal ini memiliki patofisiologi yang sama. Satu abad kemudian, Virchow mengkonfirmasi hipotesis Galeneus akibat ditemukannya leukosit pada tumor, sehingga yang ditemukan kaitan antara inflamasi dan kanker, dan pada dekade terakhir telah jelas ditemukan adanya hubungan bahwa inflamasi memainkan peranan penting pada tumorigenesis. Hanya sedikit jenis tumor yang disebabkan oleh mutasi gen. Banyak faktor lingkungan yang menjadi 
penyebab dan faktor risiko tumor yang berhubungan dengan inflamasi. Pada pemeriksaan subklinik, inflamasi yang tidak terdeteksi dapat menjadi faktor penting terjadinya tumor. ${ }^{8,9,10}$

Inflamasi berpengaruh pada setiap tahap dari tumorigenesis, dari inisiasi melalui promosi tumor, sampai progresi ke metastasis. Dalam perkembangan antitumorigenik dan imun protumorigenik ikut berperan dalam suatu mekanisme perdangan. Jika tumor tidak ditolak oleh tubuh, maka efek protumorigenik menjadi dominan. Signaling pathway yang memediasi efek protumorigenik dari inflamasi sering terkait dengan tumorigenesis. Beberapa komponen imun dan inflamasi yang tidak ditemukan pada satu tahap dari tumorigenesis, dapat menjadi sangat penting pada tahap lainnya. ${ }^{8,9,10}$

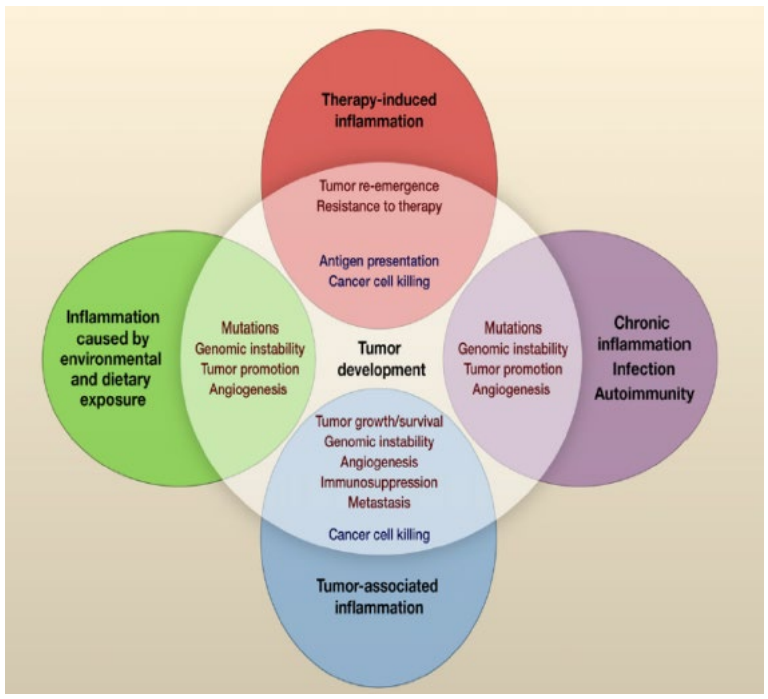

Gambar 1. Diagram hubungan antara tumor dengan inflamasi. ${ }^{9}$

\section{LAPORAN KASUS}

Dilaporkan kasus seorang perempuan berusia 51 tahun, datang ke poliklinik THT tanggal 29 September 2014 dengan keluhan telinga kiri berair, hilang timbul sejak 30 tahun yang lalu. Cairan hilang timbul terutama jika pasien demam, batuk, dan pilek. Riwayat bengkak di belakang telinga kiri tidak ada, nyeri telinga tidak ada, riwayat penurunan pendengaran pada telinga kiri ada, riwayat penurunan kesadaran, kejang-kejang, muntah menyemprot dan sakit kepala hebat tidak ada, demam batuk pilek tidak ada. Pasien sudah berobat ke spesialis THT pada praktek swasta dan disarankan untuk dilakukan operasi.

Pada pemeriksaan status generalis, keadaan umum baik, kesadaran komposmentis kooperatif, suhu afebris. Pada status lokalis THT, telinga kanan; liang telinga lapang, membran timpani utuh, refleks cahaya baik. Telinga kiri; liang telinga lapang, membran timpani perforasi sentral, sekret mukoid. Pada hidung, kavum nasi lapang, konka inferior eutrofi, konka media eutrofi, tidak ada sekret, tenggorok, arkus faring simetris, uvula di tengah, tonsil T1-T1 tenang, dinding posterior faring tenang. Dilakukan test penala didapatkan hasil tuli konduktif pada telinga kiri. Pasien kemudian didiagnosis Otitis Media Supuratif Kronis (OMSK) tipe aman fase aktif. Dilakukan Computed Tomography (CT) Scan mastoid, kultur sekret telinga, audiometri. Terapi ofloksasin tetes telinga dan $\mathrm{H} 2 \mathrm{O} 2$ $3 \%$ sebanyak $2 \times 5$ tetes pada telinga kiri dan siprofloksasin tablet $2 \times 500 \mathrm{mg}$.

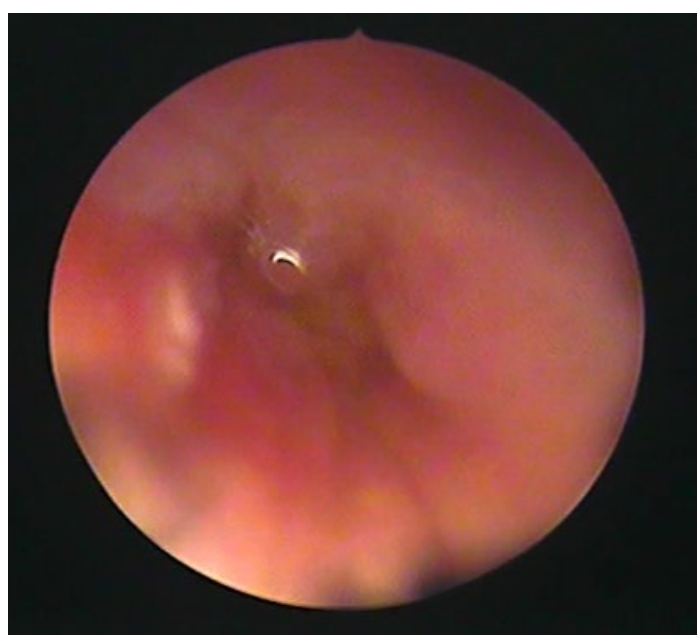

Gambar 2. Liang telinga kiri.

Saat kontrol tanggal 21 Oktober 2014 di subbagian otologi, pasien datang masih dengan keluhan yang sama, namun pada pemeriksaan fisik ditemukan adanya jaringan granulasi di liang telinga kiri (gambar 2) dan dilakukan ekstraksi jaringan granulasi, kemudian jaringan tersebut diperiksakan ke bagian Patologi Anatomi (PA). Hasil pemeriksaan PA tampak jaringan ikat mengandung kapiler yang hiperemik, kelompok sel limfosit, sel plasma, dan sedikit epitel berlapis gepeng dengan diagnosis radang kronik pada liang telinga kiri.

Hasil CT scan keluar pada tanggal 7 Oktober 2014. Pada pemeriksaan CT scan mastoid potongan koronal dan aksial tampak perselubungan di antrum dan periantrum mastoid kiri, air cell mastoid kiri menghilang, koklea baik, air cell mastoid kanan baik, koklea baik. Tidak tampak destruksi pada tulang mastoid kanan dan kiri, Meatus akustikus internus dan eksternus kanan dan kiri terbuka, tegmen timpani intak, tidak tampak erosi, tidak tampak kolesteatom pada mastoid kiri. Kesimpulan mastoiditis sinistra. (gambar 3)

Tanggal 10 Oktober 2014 hasil kultur dan sensitifitas keluar dengan jenis bakteri Staphylococcus aureus, dan masih sensitif dengan kloramfenikol, sulfametoksazol, sefotaksim, gentamisin, seftriakson, seftazidim, dan fosfomisin, dan resisten terhadap amoksisilin dan memberikan respon intermediet dengan nalidix acid. Selanjutnya pasien rutin kontrol berkala ke poli THT karena telinga kirinya masih berair. 

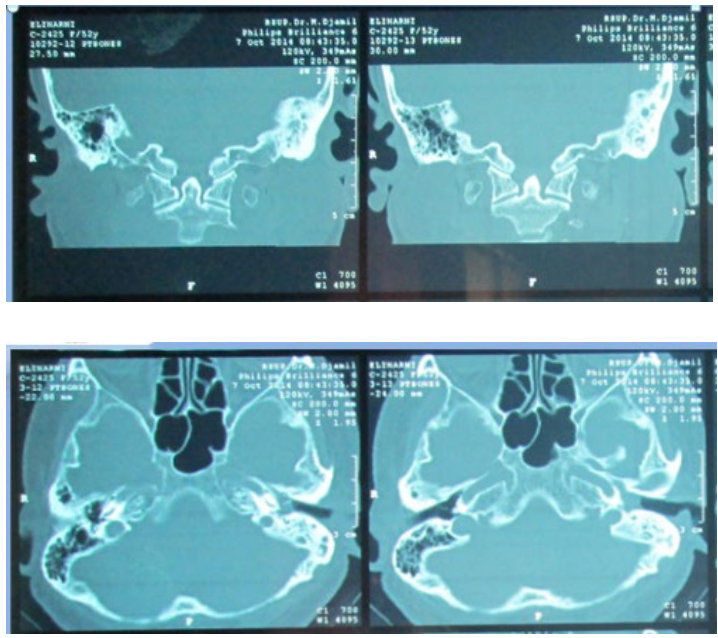

Gambar 3. CT Scan Mastoid dengan kesan mastoiditis sinistra

Tanggal 14 Januari 2015 pasien dikonsulkan ke bagian neurotologi, dilakukan pemeriksaan penala $128 \mathrm{~Hz}, 256 \mathrm{~Hz}, 512 \mathrm{~Hz}, 1024 \mathrm{~Hz}, 2048 \mathrm{~Hz}$, untuk telinga kiri dengan hasil; Rinne negatif, Webber lateralisasi ke kiri dan Scwabach memanjang. Pada pembacaan audiometri memberikan hasil ambang dengar telinga kanan normal $20 \mathrm{~dB}$, dan telinga kiri tuli konduksi derajat sedang dengan ambang dengar 42,5 $\mathrm{dB}$. Dilakukan test keseimbangan sederhana dan koordinasi semuanya dapat dilakukan. Pemeriksaan Gustatometri normal, Schimer test normal, dan pada pemeriksaan $\mathrm{N}$. fasialis didapatkan HB I dan tidak ditemukan parese. Pasien didiagnosis OMSK AS tipe aman fase aktif, tidak ditemukan parese N. VII perifer dengan HB I dengan fungsi motorik 100\% + tuli konduksi telinga kiri.

Pasien direncanakan untuk tindakan timpanomastoidektomi dinding utuh pada telinga kiri tanggal 28 Juli 2015. Satu hari sebelum operasi pasien di informed consent, puasa 6-8 jam, di periksa darah rutin, PT dan APTT, cukur rambut daerah temporal sinistra, konsul anestesi dan penyakit dalam, diberikan terapi seftriakson $2 \times 1 \mathrm{gr}$ intravena. Saat operasi pasien tidur berbaring miring ke kanan dalam anestesi umum. Dilakukan tindakan aseptik dan antiseptik pada lapangan operasi, dipasang duk steril. Evaluasi liang telinga, tampak jaringan granulasi, di sekitar jarigan granulasi di temukan jaringan berpapilpapil curiga tumor. (gambar4)

Tampak membran timpani perforasi subtotal, sekret mukoid. Dilakukan insisi $2 \mathrm{~mm}$ dari sulkus retroaurikula sampai terlihat fasia muskulus temporalis, fasia diambil untuk graft. Insisi dilanjutkan tangensial terhadap liang telinga, dilakukan penelusuran kortek mastoid. Identifikasi segitiga MacEwen, dilakukan pengeboran pada daerah mastoid, air cell dibersihkan, tidak ditemukan adanya kolesteatom, ditemukan adanya jaringan granulasi yang dikelilingi bagian yang massa kenyal padat berpapil yang dicurigai suatu tumor mengisi antrum, aditus ad antrum sampai ke mukosa telinga tengah yang kemudian dibersihkan semuanya.

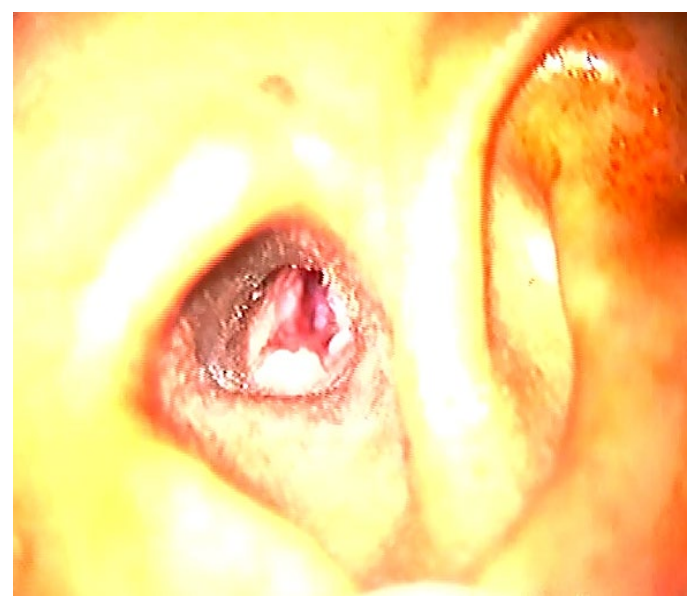

Gambar 4. Temuan intraoperatif, jaringan berpapil curiga tumor.

Maleus destruksi. Setelah semua bagian tumor dibersihkan, termasuk pada bagian kulit tiang telinga di dekat membran timpani, dilakukan trimming pada pinggir perforasi membran timpani, dan pemasangan graft, difiksasi dengan spongostan dan tampon softratule. Dipasang drain, luka insisi dijahit lapis demi lapis. Operasi selesai. Jaringan granulasi yang berpapil tersebut dikirim untuk pemeriksaan patologi anatomi. Diagnosis pasca timpanomastoidektomi dinding utuh atas indikasi OMSK tipe aman fase aktif dengan suspek tumor liang telinga. Pasca operasi pasien diberikan terapi seftriakson $2 \times 1 \mathrm{gr}$, deksametason $3 \times 5 \mathrm{mg}$, drip tramadol $100 \mathrm{mg}$ dalam 1 kolf RL habis dalam 8 jam.

Pada follow up pertama, satu hari pasca operasi, tidak ditemukan adanya wajah mencong, tidak ada pusing berputar, tidak ada mual muntah, tidak ada demam. Pada pemeriksaan fisik telinga kiri, tidak tampak darah merembes ke kasa. Pasien didiagnosis pasca timpanomastoidektomi dinding utuh hari pertama atas indikasi OMSK AS tipe aman fase aktif dengan suspek tumor liang telinga.

Pada follow up ke tiga, 3 hari pasca operasi pasien juga tidak mengeluhkan adanya wajah mencong, pusing berputar, mual, muntah, dan juga tidak demam. Dilakukan pembukaan drain telinga, dan tampon luar. Pasien diperbolehkan pulang dan diberikan terapi kloramfenikol $3 \times 500 \mathrm{mg}$, asam mefenamat $3 \times 500 \mathrm{mg}$, ofloksasin tetes telinga $2 \times 5$ tetes telinga kiri dan disarankan untuk kontrol ke poli THT 3 hari lagi.

Tanggal 3 Agustus 2015, (hari ke 6 pasca operasi) pasien kontrol ke poli THT, pasien tidak mengeluhkan adanya wajah mencong, pusing berputar, nyeri telinga, dan tidak demam. Pasien membawa hasil pemeriksaan patologi anatomi, didapatkan kesimpulan neurofibroma dengan kalsifikasi. (gambar 5)

Pada evaluasi telinga kiri tertutup tampon, tidak tampak darah merembes dari tampon. Evaluasi daerah retroaurikula sinistra, dan dilakukan 
pembukaan jahitan, luka insisi tenang. Terapi kloramfenikol $3 \times 500 \mathrm{mg}$ dan ofloksasin $2 \times 5$ tetes telinga kiri.

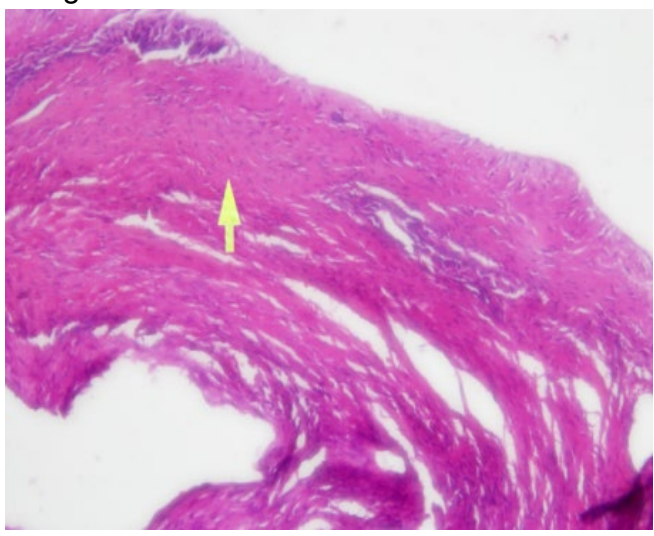

Gambar 5. Tampak gambaran sel saraf pada sediaan patologi anatomi

Tanggal 14 Agustus 2015 (14 hari pasca operasi) pasien tidak mengeluhkan keluar cairan dari telinga kiri, tidak ada nyeri telinga, tidak ada pusing berputar dan wajah mencong. Dilakukan pengangkatan tampon dalam. Dilakukan ear toilet, dan di evaluasi liang telinga tampak lapang dan graft pada posisi yang baik. Tidak ada sekret. Terapi ofloksasin tetes telinga masih dilanjutkan. Pasien disarankan untuk kontol teratur seminggu sekali sampai 4 minggu pasca operasi.

Tanggal 28 Agustus 2015 (1 bulan pasca operasi) pasien kontrol, tidak ada keluhan demam, nyeri telinga, keluar cairan dari telinga. Pada otoskopi telinga kiri ditemukan liang telinga kiri lapang, graft tumbuh dengan baik. Seterusnya pasien dianjurkan untuk kontrol teratur tiap dua minggu sampai bulan ke dua dan sesudahnya satu bulan sekali.

Pada 28 Oktober 2015 pasien datang untuk kontrol, tidak ada keluhan keluar cairan dari telinga kiri, tidak ada keluhan telinga terasa penuh, tidak ada demam. Pada otoskopi didapatkan liang telinga kiri lapang, graft tumbuh dengan baik (gambar 6). Pasien dilakukan audiometri pasca operasi, dengan hasil $48,75 \mathrm{~dB}$. Selanjutnya pasien disarankan untuk kontrol satu bulan kemudian.

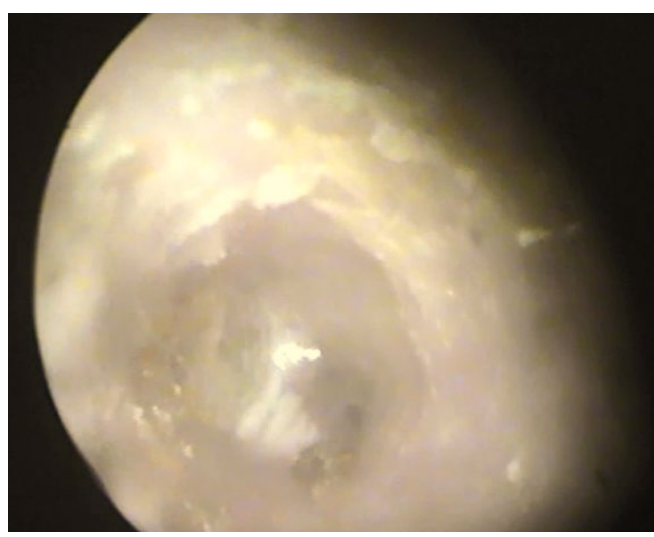

Gambar 6. Otoskopi bulan ketiga

\section{PEMBAHASAN}

Pasien datang dengan keluhan telinga berair hilang timbul sejak 30 tahun yang lalu, Keluhan ini merupakan keluhan klasik yang khas untuk menandakan adanya peforasi kronis pada membran timpani. Namun pasien tidak mengeluhkan adanya rasa penuh di telinga atau telinga tersumbat. Pasien hanya mengeluhkan adanya penurunan pendengaran Hal ini dikaburkan dengan kondisi bahwa pasien telah mengalami riwayat telinga berair cukup lama (30 tahun) yang juga telah mengganggu pendengarannya sehingga keluhan telinga terasa penuh tidak terlalu dikeluhkan pasien. Namun pada kasus dimana telah terdapat perforasi membran timpani ataupun ada massa pada liang telinga atau kavum timpani, maka dapat timbul tuli konduktif, seperti yang juga dialami oleh pasien ini. 4,5

Pada pemeriksaan fisik liang telinga $1 / 3$ dalam, tampak adanya jaringan granulasi yang dikelilingi daerah berpapil-papil, hal serupa juga ditemukan intraoperatif pada telinga tengah. Neurofibroma berasal dari sel saraf perifer, dapat tumbuh dimana saja di tubuh yang memiliki saraf, muncul di dermis dan meluas ke daerah subkutan. Menurut Collin dan Hallpike seperti yang dikutip oleh Lustig $^{8}$ pada keadaan yang sangat jarang tumor pada telinga tengah dapat muncul dari saraf Arnold (cabang aurikular dari nervus vagus) atau saraf Jacobson (cabang timpani dari saraf kranial kesembilan).

Pada pemeriksaan audiometri pasien ini didapatkan hasil tuli konduksi dengan ambang dengar 42,5 dB. Menurut Collin dan Hallpike seperti yang dikutip oleh Lustig $^{8}$, jika tumor memang berasal dari saraf Arnold atau Jacobson, maka tumor ini dapat menekan tulang pendengaran atau bahkan dapat memfiksasi kaki stapes sehingga mengakibatkan terjadinya tuli konduksi, ditambah pula adanya penebalan pada liang telinga juga berperan serta menimbulkan tuli konduksi pada pasien ini. ${ }^{8}$

Neurofibroma terkait dengan faktor genetika, untuk itu ditanyakan riwayat keluarga pasien, karena menurut literatur, perubahan gen yang menjadi salah satu penyebab neurofibroma pada penyakit neurofibromatosis dapat diturunkan dalam keluarga. Pada pasien ini tidak ada keluarga dengan keluhan yang serupa, namun bisa saja hal ini sesungguhnya tidak terperhatikan mengingat bahwa tumor ini jinak, dan jika berukuran kecil, dapat tumbuh tanpa gejala. 1,4,8,11,12,13

Pada pasien ini dilakukan tindakan timpanomastoidektomi dinding utuh. Saat operasi tumor ditemukan di telinga tengah bersamaan dengan jaringan granulasi dan saat itu dibersihkan seluruhnya. Hal yang sama juga ditemukan dalam beberapa literatur yang mengatakan bahwa tatalaksana untuk neurofibroma adalah reseksi. 1,4,5,8 Namun karena pada kasus ini terjadi bersamaan dengan OMSK tipe aman fase aktif, maka sekaligus dilakukan juga timpanomastoidektomi dinding utuh. 
Menurut Trevisani et al seperti dikutip oleh Ghosh1, eksisi komplit mungkin dilakukan jika tidak terdapat kontraindikasi. Lesi yang luas mungkin memerlukan rekonstruksi. Tumor ini umumnya sering kambuh lagi dan memerlukan terapi paliatif. ${ }^{1}$ Pada kasus ini lesi selama 3 bulan follow up secara otoskopi tidak ditemukan adanya penebalan di liang telinga.

Hasil audiometri tiga bulan pasca tindakan adalah 48,75 dB. Hal ini sesuai karena intraoperatif didapatkan destruksi maleus. Pada keadaan hilangnya maleus dan atau inkus dan atau stapes, kopling osikuler hilang, bersama dengan bertambahnya kopling akustik karena hilangnya halangan membran timpani. Tuli konduktif (ABG) sekitar $60 \mathrm{~dB}$ yang disebabkan oleh hilangnya kopling osikel akan diperbaiki sedikit oleh bertambahnya kopling akustik sebesar sekitar 10-20 dB karena hilangnya hambatan oleh membran timpani yang tak ada lagi. Sebagai resultante, ABG akan menjadi sekitar $49 \mathrm{~dB} .{ }^{6}$

Hasil patologi anatomi mendiagnosis tumor yang ditemukan adalah neurofibroma, hal ini tidak semata-mata langsung menjadikan pasien didiagnosis sebagai penderita neurofibromatosis, khususnya NF tipe 1. Menurut sebuat review oleh POSNA (Pediatric Orthopaedic Society of North America) seperti yang dikutip oleh Ghosh et al $^{1}$ terdapat juga penderita yang memiliki neurofibroma namun tidak menderita neurofibromatosis tipe 1 (NF1). Hal yang sama juga teradi pada pasien ini. Tidak ditemukan adanya tanda NF1 pada pasien ini. Adapun tanda NF1 adalah ditemukannya minimal dua delapan kritria, yaitu caféau-lait spots, dengan diameter lebih dari $15 \mathrm{~mm}$ pada pasien post pubertal, adanya bintik-bintik di ketiak atau inguinal, ditemukan dua atau lebih neurofibroma, ditemukan dua atau lebih iris hamartomas, adanya optic glioma, gangguan pada tulang, adanya keluarga yang juga memiliki kriteria tersebut. 1,14,15

Pada kasus ini neurofibroma ditemukan dengan OMSK. Sebagaimana telah diketahui, proses peradangan memiliki peranan penting dalam terbentuknya tumor. Menurut Rosana Risquest, spesialis dalam bidang proses inflamasi di Universitas Washington di Seattle USA, seperti yang dikutip oleh Hunter ${ }^{11}$ mengatakan bahwa sudah jelas infeksi kronis terlibat pada setiap level dari tumorigenesis. Termasuk inisiasi, promosi, konversi ke arah keganasan, invasi, dan metastasis akhir. Dijelaskan pula bahwa proses awal mengikutsertakan kerusakan DNA yang diakibatkan oleh oksigen reaktif yang diproduksi oleh sel imun. Alur inflamasi pada proses ini sudah jelas, dan diduga mengikutsertakan signaling dan cross-talk antara sel tumor dan host sistem imun. Ditambah pula peran microenvironment dari inflamasi sangat penting untuk semua tumor, meskipun mekanisme penyebab belum dipastikan sepenuhnya. ${ }^{11}$

\section{SIMPULAN}

Neurofibroma adalah suatu tumor selubung saraf perifer yang dapat muncul dimana saja dan diderita oleh siapa saja, namun keberadaan tumor ini di telinga tengah masih jarang ditemui dalam literatur.

Ditemukannya neurofibroma pada pasien ini, tidak menjadikannya di diagnosis menderita neurofibromatosis tipe 1, karena tidak memenuhi kriteria diagnosis. Kasus Neurofibroma pada telinga tengah dapat muncul dari saraf Arnold (cabang auricular dari nervus vagus) atau saraf Jacobson (cabang timpani dari saraf kranial kesembilan).

Pada kasus ini, neurofibroma ditemukan bersamaan dengan OMSK, walaupun belum dapat dipastikan hubungan antara inflamasi kronis dengan kejadian tumor dapat dipertimbangkan.

Pada kasus ini dilakukan timpanomastoidektomi dinding utuh dan follow up selama tiga bulan tidak menunjukkan adanya kekambuhan. Tatalaksana dan follow up yang teratur dapat memberikan hasil akhir yang baik.

\section{DAFTAR PUSTAKA}

1. Gosh SK, Chakraboroty D, Ranjan R, Barman D. Neurofibroma of the External Ear- Case Report. Indian J-. Otolaryngol. Head Neck Surg. 2008; 60: $289-290$.

2. Spyk SL, Thomas N, Cooper DN, Upadhayaya M. Neurofibromatosis type I- associated tumours: their somatic mutational spectrum and pathogenesis. Human Genomic. Vol 5. N0 6. 2011; 623-690

3. Baykal C, Yazgano KD. Neural skin tumor in clinical atlas of skin tumors. London. Spinger. 2014. 231-243

4. Minoda R, Ise M, Murakami D, Kumai Y, Yumoto E. Surgical removal of diffuse-type neurofibroma involving the auditory external canal in a patient with neurofibroatosis type 1. Int. Adv. Otol. 2012; 8: (3) 497-502.

5. Miyamoto RT, Campbell RL, Roos KL, Worth RM. Contemporary management of neurofibromatosis. Ann Otol Rhinol Laryngol 100: 1991; 38-43

6. Helmi. Otitis Media Suppurative Kronik. Jakarta. Fakultas Kedokteran Universitas Indonesia. 4274.

7. WHO. Chronic suppurative otitis media burden of illness and management option. Child and Adolescent Health and Development Prevention of Blindness and Deafness. WHO Geneva, Switzerland 2004.

8. Lustig LR, Jackler RK. Neurofibromatosis type I involving the external auditory canal. Otolayngol Head Neck surg 1996; 114:299-307.

9. Grivennikov SI, Greten FR, Karin M. Immunity, inflammation and cancer. Cell, 2010; 140; 883899.

10. Okada F. Inflamation-related carcinogenesis: current findings in epidemiological trends, causes and mechanisms. Yonago Acta Medicina 2014; 57: $65-72$ 
11. Hunter $P$. The inflammation theory of disease. EMBO reports, 2012; 13: 11; 623-690.

12. Gerber PA, Neumann NJ, Homey B, Matuschek C, et al. Neurofibromatosis. Eur J Med Res 2009. 14: 102-105.

13. Geller M, Junior LGD, Filbo AB, Robeiro MG. Plexiform neurofibroma in the ear canal of a patient with type 1 neurofibromatosis. Braz J Otorhinolaryngol 2009; 75(1): 158

14. Genetic in family medicine: The Australian handbook for general practitioner. 2007. 3-7.

15. Korf BR, Scheider G, Frenkel DP. Facing neurofibromatosis: a guide for teens. Children's tumor foundation; Ending neurofibromatosis trough research. 